\title{
Health in old age, and patients' approaches to telemedicine in Poland
}

\author{
Leszek Buliński ${ }^{1, A-F}$, Aleksandra Błachnio ${ }^{2, A-D}$ \\ ${ }^{1}$ Ateneum University, Gdansk, Poland \\ 2 Institute of Psychology, The Kazimierz Wielki University, Bydgoszcz, Poland \\ A - Research concept and design; B - Collection and/or assembly of data; C - Data analysis and interpretation; \\ $D$ - Writing the article; $E$ - Critical revision of the article; F - Final approval of article
}

Buliński L, Błachnio A. Health in old age, and patients' approaches to telemedicine in Poland. Ann Agric Environ Med. $2017 ; 24(2)$ : $322-328$.

\begin{abstract}
Introduction. The ageing society of Poland still experiences health-related problems and increasing difficulties in receiving medical care. The initiation of telemedicine programmes can change this situation for the better. The question arises whether telemedicine is a solution that the elderly are willing to accept and take advantage of in order to raise their quality of life. Objective. The aim of the research was an investigation of the quality of life and the course of ageing among the elderly Polish population, and their openness to the notion of telemedical services.

Materials and method. A questionnaire-based study was conducted in 2015 on a sample group of 312 seniors. The respondents completed the Diener Satisfaction with Life Scale (SWLS) and the subscale of Health States from Fragebogen zur Lebenszufriedenheit (FLZ) by Fahrenberg et al. Each participant gave consent to take part in the research.

Results. SWLS presents a relatively stable value in the subsequent decades of old age (60-69 years, $M=21.93, S D=6.25$; $70-79$ years, $M=21.70, S D=5.52 ; 80$ +yeasrs, $M=21.38, S D=5.82$ ). The health related quality of life (the FLZ subscale) varied in the analysed subgroups $(F=7.783: p=0.000)$ and was related to comorbidity and polytherapy. A positive attitude towards telemedicine was expressed by $40 \%$ of those surveyed. However, the need of the seniors for telemedicalservices was limited and did not exceed the $10 \%$.

Conclusions. In Poland, in ageing there still dominates the experience of multiple ailments and polytherapy, something which justifies a search for new, easily accessible, and economically sound solutions for health care. Telemedicine is a promising solution, although there is a need for definite steps to be taken to increase the willingness among geriatric patients to take advantage of telemedicine.
\end{abstract}

- Key words

ageing, telemedicine, quality of life

\section{INTRODUCTION}

The process of an increasingly ageing society raises fears in the modern world in relation to the inability of health and social services to cope with the phenomenon. Multiple illnesses and polytherapy constitute a problem in advanced years and compel the elderly to seek specialist help. However, the number of geriatric specialist doctors and centres is limited; for example, in Poland there is only one geriatric hospital, The John Paul II Hospital in Katowice, the Centre for Research into Ageing at the Medical University in Łódź, the Geriatric Centre in Wrocław and the National Institute for Geriatric Medicine, Rheumatology and Rehabilitation in Warsaw [1]. Hospitals simply do not have enough geriatric beds at their disposal [2], and hospital wards are unable to provide for extended periods of convalescence. Besides these shortfalls, there is also an absence in the numbers of specialist staff, as well as in the range of social care services for geriatric patients. The environmental care given to the elderly, particularly in relation to nursing and carer treatment and provided in patients' homes by district nurses in Poland, is a marginal activity as a result of the unresolved legalfinancial barrier [3]. Fundamentally, the healthcare system does not have at its disposal the resources necessary for the

Addres for correspondence: Leszek Buliński, Ateneum University, 3 Maja 25a 80-802 Gdańsk, Poland

e-mail: gda-med-poludnie@wp.pl

Received: 17 December 2016; accepted: 29 May 2017; first published on June 2017 needs of an ageing society [4]. Today, $15 \%$ of society is made up of those over the age of 65, yet in the near future (around the year 2050) this percentage will have risen to $27-29 \%$ [5].

The difficult situation faced by the geriatric patient forces one to seek innovative solutions within the field of telemedicine and telehealth. The broad use of telecare and telegeriatric mobile applications constitutes a chance to improve the quality of life of patients aged over 60 , as well as to increase the quality of health treatment services and their accessibility through a lowering, or at least no increase, in their costs (the so-called 'iron triangle of health care') [6].

\section{OBJECTIVE}

The literature discusses the problem of the increasing average life expectancy while simultaneously asking questions about the state of health and functional ability of seniors. Data from western countries are moderately optimistic [7]. In Poland, the tendency is rather negative, with the ageing population being characterised by a low psycho-physical condition of seniors [8], the growth in the medicalisation of their lives and an increase in multiple ailments [1]. The current study reviews reports on the levels of the quality of life in old age, multiple ailments and polytherapy of the Polish elderly population, and an examination of the attitudes prevalent with regard to utilising telemedicine among geriatric patients 
from three cohorts who, at present, represent 60 -year, 70 year, and 80 -year olds.

\section{MATERIALS AND METHOD}

A questionnaire together with an interview was carried out in 2015 on a sample of 312 seniors equally matched in terms of gender. The criteria for research inclusion were: having reached the age of 60 , Polish citizenship, no illnesses likely to result in death within the subsequent six months and an absence of serious cognitive disturbances. The answers provided by the participants were analysed in three numerically equal subgroups $(\mathrm{N}=104)$ representing 60-year, 70-year, and 80-year-olds. Detailed statistics from the study are presented in Table 1 . The survey was conducted individually after the person tested had agreed to participate in the research. Data was collected on the quality of life and the quality of life connected with health, a self-description of health, attitude towards telemedical services, as well as socio-demographic variables (including gender, education level, marital status, household).

Quality of life. The Satisfaction with Life Scale (SWLS) by E. Diener, R.A. Emmons, R. J. Larson and S. Griffin in its Zygfryd Juczyński adaptation was used for a general evaluation of the quality of life [10]. The SWLS comprises five statements evaluated on a scale from $1-7$ (from 1 - strongly disagree to 7 - strongly agree).

Quality of life and state of health. The participants completed in the subscale on State of Health from the Satisfaction with Life Questionnaire (Fragebogen zur Lebenszufriedenheit - FLZ) by J. Fahrenberg, M. Myrtek, J. Schumacher and E.Brahler $[12,13]$. This comprises seven items which describe one's state of health. The participant describes to what degree they are satisfied/dissatisfied with their state of health (e.g.: I am .... with the state of my health .... When I think how often I am plagued by pain, then I am....). The statements are assessed on a seven-point scale (from 1 - I am extremely unsatisfied to 7 - I am very satisfied).

A structured interview was conducted individually with each participant. This covered questions diagnosing the problem of multiple ailments and polytherapy. Sample:

I am under constant medical care because of illnesses of: the circulatory system, respiratory system, alimentary system, urinary system, skin diseases, motor system, cancers, others. I take medicines systematically as a result of illnesses of: the circulatory system, respiratory system, alimentary system, urinary system, skin diseases, motor system, cancers, others; How often did you take pain killers during the last week.

The 20 questions in the interview asked about the attitudes of the participant towards telemedicine. Sample questions:

Do you have a computer at home? Is the computer used for the Internet? Is it used for another purpose? Do you use electronic registration for medical appointments by means of the Internet? Have you had a medical teleconsultation with a doctor over the phone (a mobile) and/ or through the Internet (videoconference)? Would you like to have distant monitoring of basic parameters (blood pressure, electrocardiogram, blood glucose levels, weight, body temperature)?

Table 1. Socio-demographic characteristics of the test sample

\begin{tabular}{lcc}
\hline & $\begin{array}{c}\text { Men } \\
(\mathrm{N}=157)\end{array}$ & $\begin{array}{c}\text { Women } \\
(\mathrm{N}=155)\end{array}$ \\
\hline Age (average, standard deviation) & $74.63(8.34)$ & $74.08(8.41)$ \\
\hline Marital status (N, \%) & $13(8.28 \%)$ & $4(2.58 \%)$ \\
\hline single & $110(70.10 \%)$ & $78(50.32 \%)$ \\
\hline married & $18(17.83 \%)$ & $69(44.52 \%)$ \\
\hline widower/widow & $5(3.19 \%)$ & $4(2.58 \%)$ \\
\hline divorced & $1(0.60 \%)$ & - \\
\hline no data & $25(15.92 \%)$ & $52(33.55 \%)$ \\
\hline Level of education (N, \%) & $61(38.85 \%)$ & $39(25.16 \%)$ \\
\hline primary & $21(13.38 \%)$ & $14(9.03 \%)$ \\
\hline vocational primary level & $21(13.38 \%)$ & $32(20.65 \%)$ \\
\hline secondary vocational & $26(16.56 \%)$ & $17(10.97 \%)$ \\
\hline secondary school leaving certificate & $3(1.91 \%)$ & $1(0.64 \%)$ \\
\hline higher & $2(1.27 \%)$ & $3(1.90 \%)$ \\
\hline no data & $31(19.75 \%)$ & $42(27.10 \%)$ \\
\hline Household (N, \%) & $52(52.23 \%)$ & $53(34.20 \%)$ \\
\hline live alone & $57(36.80 \%)$ \\
\hline live with spouse/partner & & \\
\hline live with family & & \\
\hline no data & & \\
\hline
\end{tabular}

Statistical analysis. The data was statistically analysed by the Statistica 12.5 programme. In determining the first research question about whether the process of ageing among Polish seniors is characterised by a weak psycho-physical condition (e.g., a low quality of life, multiple ailments and polytherapy), descriptive statistics, analysis of correlation and analysis of variance (ANOVA) were applied. The second research question about the stance of older people in relation to telemedicine, was resolved on the basis of an analysis of descriptive statistics and an analysis of regression.

\section{RESULTS}

During the first stage of the study, the subjective measures of quality of life, i.e., satisfaction with life, were diagnosed. Analysis of the variance in the sense of satisfaction with life on the part of the participants in subgroups based on gender $(\mathrm{F}=0.077 \mathrm{p}=781)$ and age divisions $(\mathrm{F}=0.227 ; \mathrm{p}=0.796)$, did not display any significant statistical differences. The average results with deviations obtained in SWLS for the 60, 70 and 80 -year-olds are presented in Figure 1. The general measure of satisfaction with life for all participants $(M=21.673$; $\mathrm{Sd}=5.855)$ compared with results obtained in a Polish normalised study $(\mathrm{N}=555$, in the age group of 20 - 55-year-olds) $(\mathrm{M}=20.37$; $\mathrm{Sd}=5.32[10])$, present a relatively high level. This, however, is clearly lower than the results for American seniors ( $M=24.40$; $\mathrm{Sd}=6.99)$ [10].

Measurement of the subjective evaluation of quality of life in the area of state of health on the basis of the FLZ questionnaire proved to be more sensitive [13]. This showed 


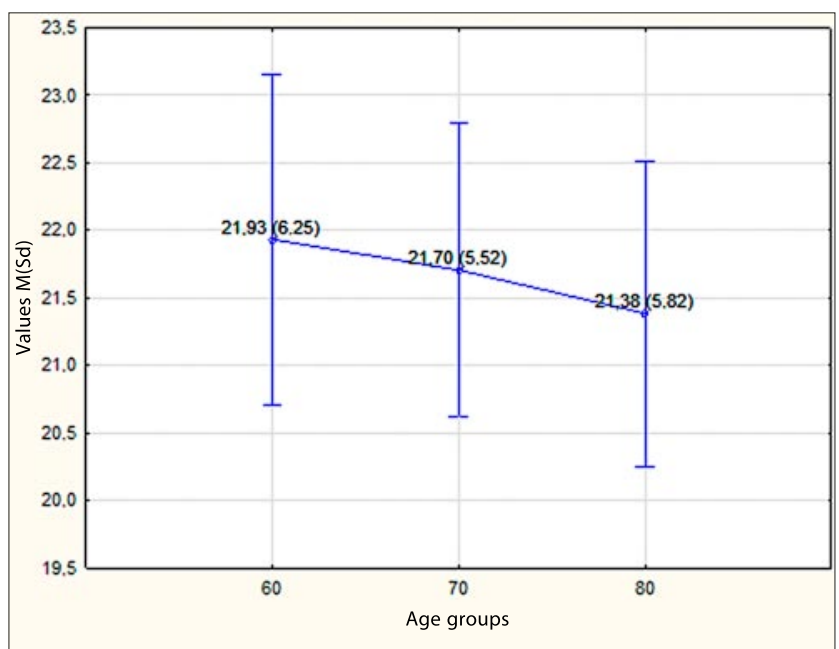

Figure 1. General assessment of quality of life (SWLS) in the age subgroups for $60-, 70$ - and 80 -year-olds

differences in the subjective evaluations of health from the aspect of respondent satisfaction with life in the three age subdivisions $(\mathrm{F}=7.783 ; \mathrm{p}=0.000)$. The participants evaluation of life satisfaction significantly diminished with age.

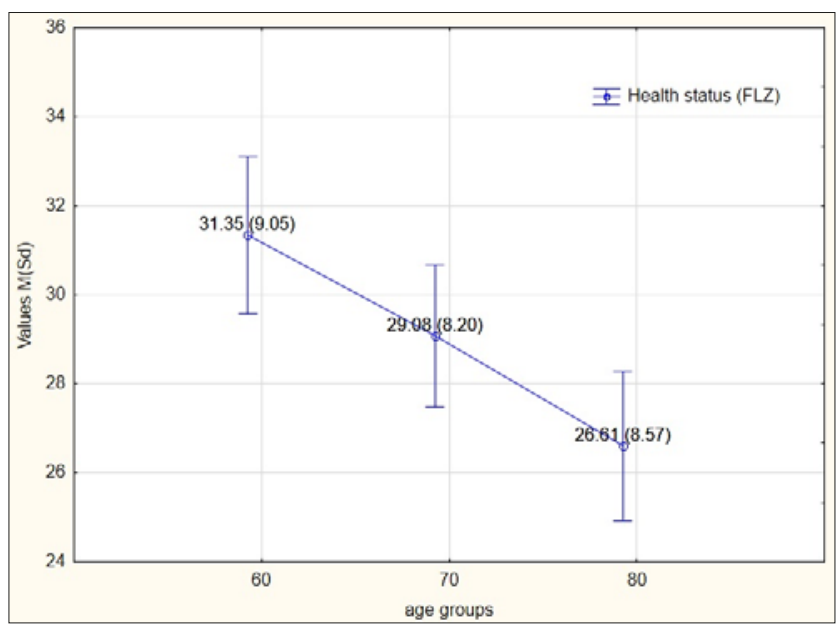

Figure 2. General evaluation of quality of life in the area of health (State of Health subscale in FLZ) in age subgroups of 60-,70- and 80 -year-olds

Measurement of the subjective quality of life correlated with the variables designating life style and the quality of ageing. The phenomenon of polytherapy was also analysed. The average of diagnosed illnesses for the 60-year-olds was $1.38(\mathrm{Sd}=1.29)$. Among the 70 -year-olds, the values were, respectively, $\mathrm{M}=1.87$ ( $\mathrm{Sd}=1.28$ ), while for the 80 -year-olds - $M=2.08$ ( $S d=1.29)$. Detailed data on the distribution of the number of ailments within the three senior age divisions is presented in Table 2.

Table 2. Multiple ailments in the consecutives decades of seniors' lives

\begin{tabular}{lcccccccc}
\hline \multirow{2}{*}{$\begin{array}{l}\text { Age } \\
\text { divisions }\end{array}$} & 0 & 1 & 2 & 3 & 4 & 5 & 6 & 7 \\
\hline & 27 & 39 & 20 & 13 & 3 & 0 & 1 & 1 \\
\hline $60-69$ & 10 & 33 & 41 & 8 & 8 & 1 & 3 & 0 \\
\hline $70-79$ & 7 & 34 & 28 & 20 & 12 & 2 & 0 & 1 \\
\hline $80+$ & & & & & &
\end{tabular}

The strength was tested of the connection between measurements of satisfaction with life and the number of diagnosed and treated illnesses, the quantity and frequency of medicament intake, with particular attention being paid to the quantity and frequency of analgesic drugs. The results of the correlation coefficients are presented in Table 3.

Table 3. Correlation coefficients of the level of quality of life with multiple illness, polytherapy and analgesics

\begin{tabular}{|c|c|c|c|c|}
\hline \multirow{2}{*}{ Variable } & \multicolumn{4}{|c|}{$\begin{array}{l}\text { Correlation matrix }(\mathrm{N}=302) \\
\text { Marked coefficients of correlation are significant with } \mathrm{p}<.05000\end{array}$} \\
\hline & Multi-illnesses & Polytherapy & Pain killers & $\begin{array}{l}\text { Frequency of } \\
\text { pain killer use }\end{array}$ \\
\hline $\begin{array}{l}\text { State of health } \\
\text { (FLZ) }\end{array}$ & -0.371 & -0.114 & -0.096 & -0.202 \\
\hline SWLS & -0.080 & -0.101 & -0.057 & -0.111 \\
\hline
\end{tabular}

The dependencies obtained show that the growing number of illnesses and the corresponding growth in pharmaceutical products taken, in particular analgesics, correlate with a decline in the satisfaction with life in old age. In poorly subsidised countries, the community of older people ageing in a positive way remains an unrealised postulate. The widespread practices of coping with ageing results most frequently in treating the symptoms, and the short-term application of pain killers. A lack of knowledge on the negative effect of polytherapy, excessive use of pain killers and abandonment of any striving for a possibly high quality of life and fitness in old age, constitute problems [14] observed not only in Poland.

There arises a justified need to verify to what degree preferred interventions and changes, at least with regard to an intensive promotion of telemedicine, and in particular tele-geriatrics, constitute valid activities in the evaluation of the seniors themselves. The aim of the questionnaire was to discover the needs of patients over 60 years of age in providing telemedicine and tele-care services. A notable majority of participants possessed a mobile phone and used it. Computers turned out to be less widespread, and among those who had never used the Internet (the percentage statistics in the Table take into consideration the division into 60, 70, and 80-year-olds) (Tab. 4). A positive change is to be witnessed among the youngest seniors (the 60 -year-olds) who, thanks to increasingly available forms of instruction on how to use a computer and the Internet, despite low levels of computer competency, have, increasingly often and willingly started to use a computer and the Internet at home [15]. This tendency was also noted in the current research.

The reactions of participants to the proposal of telemedicine and tele-care was evaluated on the basis of the answers given in the interview. The proportion of positive answers from the entire total of answers given from the whole test of seniors did take age divisions into consideration. The results obtained show that almost $40 \%$ of Polish seniors are prepared to use information-technological innovations in the health Service (Tab. 5).

Detailed analyses of answer distribution showed that the number of positive answers was disproportionate in all subgroups. A clear accumulation was observed amongst those answers given in the $60-69$ age group (cf. Fig. 3). A reverse tendency was confirmed in the answers given by the oldest participants. Negative answers dominated in evaluating the 
Table 4. Percentage of owners and/or users of mobile phones, computers and the Internet among 60-, 70-, and 80 -year-olds

\begin{tabular}{lccc}
\hline & \multicolumn{3}{c}{ Age } \\
\cline { 2 - 4 } & $\begin{array}{c}\mathbf{6 0 - 6 9} \\
N(\%)\end{array}$ & $\begin{array}{c}\mathbf{7 0 - 7 9} \\
N(\%)\end{array}$ & $\begin{array}{c}\mathbf{8 0 +} \\
N(\%)\end{array}$ \\
\hline Does not have a computer at home & $25(24.04 \%)$ & $55(52.89 \%)$ & $66(63.46 \%)$ \\
\hline $\begin{array}{l}\text { Has a computer but does not use the } \\
\text { Internet }\end{array}$ & $12(11.54 \%)$ & $27(25.96 \%)$ & $20(19.23 \%)$ \\
\hline Has a computer, uses the Internet & $67(64.42 \%)$ & $22(21.15 \%)$ & $17(16.35 \%)$ \\
\hline No data & - & - & $1(0.96 \%)$ \\
\hline TOTAL & 104 & 104 & 104 \\
\hline Does not have a mobile phone & $9(8.65 \%)$ & $19(18.27 \%)$ & $42(40.39 \%)$ \\
\hline Has a mobile phone, does not use it & - & $2(1.92 \%)$ & $2(1.92 \%)$ \\
\hline Has a mobile phone, uses it & $95(91.35 \%)$ & $83(79.81 \%)$ & $59(56.73 \%)$ \\
\hline No data & - & - & $1(0.96 \%)$ \\
\hline Total & $\mathbf{1 0 4}$ & $\mathbf{1 0 4}$ & $\mathbf{1 0 4}$ \\
\hline
\end{tabular}

usefulness of information-technological innovations in the provision of health services. The polarisation of answers are documented by data examples in Figure 3.

In the subsequent stage of analysis, an attempt was made to determine which factors mediated the need for telemedicine services in patients aged over 60 . Taken into consideration were: subjective measures of the quality of life, education level, social status, multiple illnesses, intensity and frequency of drug treatment, analgesics, possession and range in the
Table 5. Attitudes of older people to various telemedicine services

\begin{tabular}{|c|c|}
\hline Question: Which services would you like to use?: & $\begin{array}{c}\text { No. of positive } \\
\text { answers } \\
(\mathrm{N}=311) \\
\mathrm{N}(\%)\end{array}$ \\
\hline E-registration with a doctor & $130(41.80 \%)$ \\
\hline E-referral to a doctor and for specialist tests & $124(39.87 \%)$ \\
\hline Text message to remind one about a doctor's appointment & $165(53.05 \%)$ \\
\hline Text message to remind one to take medications & $98(31.51 \%)$ \\
\hline Tele-consultation with a doctor & $74(23.79 \%)$ \\
\hline E-medical file with constant distance access & $106(34.08 \%)$ \\
\hline E-register of a patient & $81(26.05 \%)$ \\
\hline $\begin{array}{l}\text { Distance monitoring of basic parameters (blood pressure, } \\
\text { electrocardiogram, body temperature, etc.) }\end{array}$ & $127(40.84 \%)$ \\
\hline Access to laboratory results online & $140(45.02 \%)$ \\
\hline Simple medical instruction sent to a senior's mobile/computer & $112(36.01 \%)$ \\
\hline $\begin{array}{l}\text { Access to e-societies (communities) suffering from the same } \\
\text { disease to share practical knowledge about drugs, procedures, } \\
\text { reimbursements, etc. }\end{array}$ & $105(33.76 \%)$ \\
\hline $\begin{array}{l}\text { E-reports on a senior's state of health sent systematically to a } \\
\text { relative (adult offspring, spouse, etc.) }\end{array}$ & $83(26.69 \%)$ \\
\hline $\begin{array}{l}\text { E-advice on a mobile on how to manage in the case of a fall, } \\
\text { palpitations, etc. }\end{array}$ & $106(34.08 \%)$ \\
\hline Intelligent house technology & $91(29.26 \%)$ \\
\hline Electronic medicine dispensers & $81(26.05 \%)$ \\
\hline Movement detectors in medicine cupboards & $32(10.29 \%)$ \\
\hline
\end{tabular}

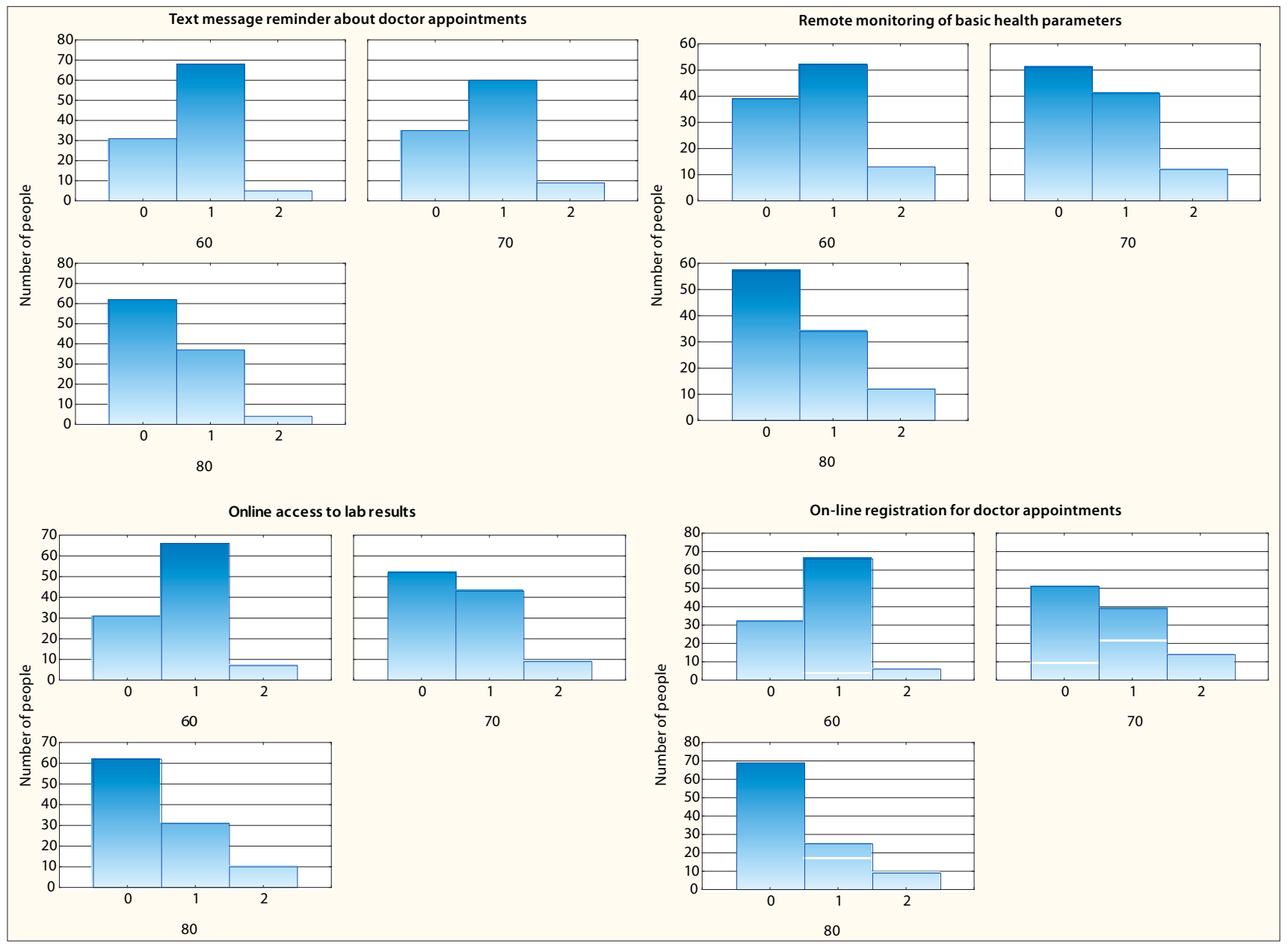

Figure 3. Openness to telemedicine among seniors from different age groups. Legend: 0 - no interest; 1 - interest; 2 -hard to tell 
Table 6. Summary of multiple regressions for selected aspects of tele-care and fundamental independent variables

\begin{tabular}{|c|c|c|c|c|c|c|}
\hline \multirow[t]{2}{*}{$\mathrm{N}=287$} & \multicolumn{6}{|c|}{ 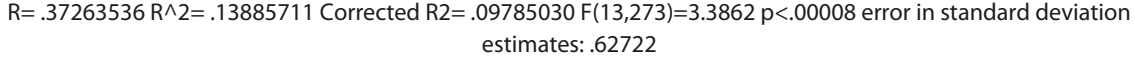 } \\
\hline & $b^{*}$ & SD from $b^{*}$ & b & SD from $b$ & $t(273)$ & $P$ \\
\hline Frequency of drug treatment & -0.129 & 0.059 & -0.006 & 0.003 & -2.174 & 0.031 \\
\hline Using a computer and/or using the Internet & 0.220 & 0.069 & 0.305 & 0.096 & 3.181 & 0.002 \\
\hline \multirow[t]{2}{*}{$\mathrm{N}=296$} & \multicolumn{6}{|c|}{$\begin{array}{c}\mathrm{R}=.35394037 \mathrm{R} \wedge 2=.12527379 \text { Corrected } \mathrm{R} 2=.08494953 \mathrm{~F}(13.282)=3.1067 \\
\mathrm{p}<.00024 \text { error in standard deviation estimates: } .64658\end{array}$} \\
\hline & $b^{*}$ & SD from $b^{*}$ & b & SD from $b$ & $t(282)$ & $P$ \\
\hline State of Health (FLZ) & 0.207 & 0.071 & 0.016 & 0.006 & 2.897 & 0.004 \\
\hline SWLS & -0.272 & 0.064 & -0.032 & 0.007 & -4.226 & 0.000 \\
\hline Multi-illnesses & 0.136 & 0.064 & 0.069 & 0.033 & 2.127 & 0.034 \\
\hline Using a computer and/or using the Internet & 0.162 & 0.069 & 0.231 & 0.098 & 2.362 & 0.019 \\
\hline \multicolumn{7}{|c|}{$\begin{array}{c}\text { Distance monitoring of basic parameters (blood pressure, electrocardiogram, body temperature, etc.) } \\
\mathrm{R}=.28167479 \mathrm{R}^{\wedge} 2=.07934069 \text { Corrected } \mathrm{R} 2= \\
.03689895 \mathrm{~F}(13.282)=1.8694 \mathrm{p}<.03340 \text { error in standard deviation } \\
\text { estimates: } .67659\end{array}$} \\
\hline & $b^{*}$ & $S D$ from $b^{*}$ & $\mathrm{~b}$ & $\mathrm{SD}$ from $\mathrm{b}$ & $t(282)$ & $\mathrm{P}$ \\
\hline Frequency of drug treatment & -0.145 & 0.060 & -0.007 & 0.003 & -2.408 & 0.017 \\
\hline Using a computer and/or using the Internet & 0.144 & 0.071 & 0.209 & 0.102 & 2.043 & 0.042 \\
\hline
\end{tabular}

\begin{tabular}{|c|c|c|c|c|c|c|}
\hline \multirow[t]{2}{*}{$\mathrm{N}=295$} & \multicolumn{6}{|c|}{$\begin{array}{c}\text { Access to e-societies by patients suffering from the same ailments in order to share practical knowledge or } \\
\text { drugs, procedures, reimbursements, etc. } \\
\mathrm{R}=.30527735 \mathrm{R}^{\wedge} 2=.09319426 \text { Corrected } \mathrm{R} 2=.05124240 \mathrm{~F}(13.281)=2.2215 \mathrm{p}<.00899 \text { error in standard deviation } \\
\text { estimates: }, 66905\end{array}$} \\
\hline & $b^{*}$ & SD from $b^{*}$ & $\mathrm{~b}$ & SD from $b$ & $t(281)$ & $P$ \\
\hline Multiple illnesses & 0.147 & 0.065 & 0.075 & 0.034 & 2.243 & 0.026 \\
\hline
\end{tabular}

Simple medical advice sent to a senior's mobile phone/computer

\begin{tabular}{|c|c|c|c|c|c|c|}
\hline \multirow[t]{2}{*}{$N=296$} & \multicolumn{6}{|c|}{ estimates: .67094 } \\
\hline & $b^{*}$ & $S D$ from $b^{*}$ & $\mathrm{~b}$ & SD from $b$ & $t(282)$ & $P$ \\
\hline State of Health (FLZ) & 0.204 & 0.072 & 0.017 & 0.006 & 2.826 & 0.005 \\
\hline SWLS & -0.161 & 0.065 & -0.019 & 0.008 & -2.468 & 0.014 \\
\hline Frequency of drug treatment & -0.136 & 0.060 & -0.007 & 0.003 & -2.290 & 0.023 \\
\hline Using a computer and/or using the Internet & 0.159 & 0.063 & 0.259 & 0.103 & 2.514 & 0.013 \\
\hline
\end{tabular}

$\mathrm{N}=296$

$\mathrm{R}=.29653921 \mathrm{R}^{\wedge} 2=.08793550$ Corrected $\mathrm{R} 2=.04588998 \mathrm{~F}(13.282)=2.0914 \mathrm{p}<.01475$ error in standard deviation estimates: 69174

\begin{tabular}{|c|c|c|c|c|c|c|}
\hline & \multirow[b]{2}{*}{$b^{*}$} & & & & & \\
\hline & & SD from $b^{*}$ & b & SD from $b$ & $t(282)$ & $P$ \\
\hline Multiple illnesses & 0.157 & 0.065 & 0.084 & 0.035 & 2.407 & 0.017 \\
\hline Frequency of drug treatment & -0.122 & 0.060 & -0.006 & 0.003 & -2.030 & 0.043 \\
\hline Using a computer and/or using the Internet & 0.138 & 0.070 & 0.206 & 0.104 & 1.969 & 0.050 \\
\hline
\end{tabular}

use of computers and mobile phones. Some statistically significant relations are shown in Table 6.

\section{DISCUSSION}

The statistics connected with the demography of ageing and old age confirm the growing percentage of those ill and infirm. In Poland, an increase in life expectancy can be observed which, however, is simultaneously linked to a high degree of disability [16]. The data collected confirmed this tendency. With age, the number of illnesses increases, as does the frequency and quantity of pharmaceutical drugs taken. This results in a systematic lowering in the quality of life, and in particular, the quality of life connected with health. In a situation in which the health service fails, alternative strategies are sought for improving the quality of the ageing process and the social care administered. Hence, the growing interest in telemedicine.

The fact that technology is entering into the lives of those ageing physiologically, as well as those with dysfunctions, chronic ailments and disabilities $[9,17,18]$ does not in itself guarantee telemedical success. The results of the presented study concerning the need for telemedical services for the ageing generation showed that these are still low, and are limited to the younger cohorts who accept information technology as something useful within everyday life. About $40 \%$ of the Polish seniors surveyed declared a willingness to use definite telemedical services; however, there was an absence of the oldest - those over the age of eighty.

Compared to the established telemedical market in the United States, Scandinavia, etc., the number of potential 
tele-patients is unsatisfactory. It is worth emphasising the this number - in a country where in point of fact access to telemedical services is marginal in number - is stable, as documented in the results of other studies [19,20]. This positive relation to telemedicine obtained amongst seniors, given their limitations in using it as a result of the high costs, complexities in the servicing and realisation of certain teleservices, is reflected in global reports. Analogical results were also obtained in Chinese studies [21].

Detailed analysis of the answers provided by the Polish participants concerning telemedicine documents their selective interest in definite concrete services. From a wide range of services available, Polish seniors considered four to be useful: on-line registration for visits, receiving reminders about appointments in the form of text messages, distant access to test results, and biometrical telemonitoring. These preference may be interpreted as evidence that seniors need a system of health care in which they themselves and their time become a resource worthy of respect. The utilisation of technology would increase the convenience and ease of looking for specialist help, while preserving the traditional form of meeting a doctor 'face-to-face.' The argument supporting this line of interpretation is borne out by subsequent results. Seniors do not perceive as attractive the tele-consultations with a doctor - only $24 \%$ replied affirmatively, with a massive $66 \%$ of those surveyed reacting negatively; $10 \%$ were undecided. The need for intimacy and directness in the relationship of a senior with their doctor saw direct reflection in their marginal interest in information about their health being made available to relatives $-27 \%$ answered: yes, $62 \%$ - no; $11 \%$ were undecided. The extensive range of smart applications - dispensers, detectors and intelligent home systems - did not exceed an interest level of $30 \%$ among the seniors.

Analyses using multiple regressions were conducted in searching for factors positively mediating the relations of seniors to telemedicine. The results obtained show that seniors with constant access to mobile devices (the Internet and mobile phones) are more inclined to regard telemedicine as necessary. General satisfaction with life negatively corresponded with the constructs aimed for, as did the increase in the intensity of polytherapy. Contrarily, satisfaction with life connected to health and multiple ailments increase with a positive relation to telemedicine. Such a contrast in terms of dependence may be explained by the limited trust in an e-service situation in which a senior does not have a personal relationship with the service provider. Therefore, although they do not fundamentally reject the usefulness of telemedicine and its optimising effect on their functioning, they decidedly more often than not make use of traditional services within the health service sector.

Because many of the analysed variables (education level, social status, multiple ailments, the intensity and frequency of polytherapy, analgesics) remained in mutual relationship at a statistically non-significant level, while the statistically significant dependencies did not form a coherent model in interpretation, nonetheless, the question arises about the reason for this state of affairs. Making use of the Technology Acceptance Model (TAM) by F.D. Davis [22], it follows that the assembled data constitute indicators of seniors' intentions to utilise telemedicine which, for many of the participants, was reinforced by any direct experience. Many participants had no knowledge or practical experience in the field of telemedicine, or in that of distance technologies. In attempting to ground their own relations to various applications for information technology in medicine, seniors based themselves on an imagined and not on a real perceived usefulness. Analogically, the perceived ease of use, particularly among the 70 and 80 -year-olds, among whom the use of a computer and the Internet remains a marginal practice (Tab. 4), was a projection. It is possible that even incidental personally positive experiences in the field of telemedicine, at least among 70 -year-olds, would positively revise their attitude to distance medical services [23]. While the promotion of e-education and tele-health in Poland, even given the weakly optimistic forecasts in terms of their systematic dissemination within the health service itself, are valuable nonetheless. Based on the Theory of Reason Action (TRA) [24], it may be conjectured that a positive change in the attitude of seniors towards telemedicine will ease in the future in the selection and use of definite telecare and telehealth services.

\section{CONCLUSIONS}

In countries like Poland where only a limited percentage of the GNP in is devoted to preventative methods and assistance for those who are ageing and the elderly themselves, a positive and healthy old age is still merely a desired and not an actual quality in the functioning of seniors. In advanced old-age, multiple illnesses and polytherapy are common. Telemedicine at present is only in its infancy and the limited willingness on the part of geriatric patients to use it is coupled with a low level of information-technology competency (IT), whch constitutes one of many limitations and barriers. Besides the need for e-education and training (instruction) in IT skills for seniors, there is a need for an analogical programme among doctors, nurses and medical-care workers in the broadest sense of the term. In addition, there is a need to develop the necessary protocols guaranteeing fundamental patient rights in an environment of telemedical applications. There also exist system barriers connected with the low budget given to the health sector and the lack of integrality and compatibility in the IT solutions implemented.

\section{REFERENCES}

1. Tanaka M, Ishii A, Yamano E, Ogikubo H, Okazaki M, Kamimura K, Konishi Y, Emoto S, Watanabe Y. Effect of a human-type communication robot on cognitive function in elderly women living alone. Med Sci Monit. 2012; 18(9): CR550-557. doi: 10.12659/ MSM.883350 [PubMed].

2. Zych A A, Piękni osiemdziesięcioletni, czyli paradygmat „starzenia się z wdziękiem" a realia życia [Beautiful Eighty-year-olds or the Paradigm of 'Ageing Gracefully' and the Reality of Life.] [in:] L. Buliński (ed.), Realność złego starzenia się. Poza polityczną i społeczną powinnością [The Reality of Ageing Badly. Beyond Political and Social Obligation], 139-156. Wydawnictwo Adam Marszałek, Toruń. 2015 [in Polish].

3. Bielawska J. Rola pielęgniarki w opiece długoterminowej [The Role of the Nurse in Long-term Care]. Zeszyty Naukowe PWSZ im. Witelona w Legnicy, 2015; 15(2): 7-20 [in Polish].

4. Derejczyk J, Bień B, Kokoszka-Paszkot J, Szczygieł J. Gerontologia i geriatria w Polsce na tle Europy - czy należy inwestować w ich rozwój w naszym kraju? [Gerontology and Geriatrics in Poland against a European Backcloth - Should Investment Be Made in Its Development Here in Poland?] Gerontologia Pol. 2009; 16(3): 149-159 [in Polish]. 
5. Okólski M. Demograficzna starość przeznaczeniem nowoczesnego społeczeństwa [Demographic Old Age - Our Society's Destiny]. Zoon Politikon. 2014; 5: 59-72 [in Polish].

6. Burns LR, D’Aunno T, Kimberly JR. Globalization and its many faces: the case of the health sector. [in:] Gatignon H, Kimberly JR, Gunther RE. (ed.) The INSEAD-Wharton alliance on globalizing. Strategies for building successful global businesses, 395-421. Cambridge University Press, Cambridge. 2004

7. Lagergren M, Johnell K, Schön P, Danielsson M. Healthy life years in old age: Swedish development 1980-2010 according to different health indicators. Scand J Public Health. 2016; 44: 55-61.

8. Błachnio A, Buliński L. Securing health: social rehabilitation and wellbeing in late adulthood. Acta Neuropsychologica. 2013; 11(3): 239-248.

9. Pąchalska M, Góral-Półrola J, Jastrzębowska G, Rasmus A, Kaczmarek BLJ, Małek A. The neurolinguistics of the US/THEM structure in aphasia. Acta Neuropsychologica 2015; 13(4): 309-330.

10. Juczyński Z. Narzędzia pomiaru w promocji i psychologii zdrowia [Instruments of Measurement in Health Promotion and Psychology]. Pracownia Testów Psychologicznych PTP, Warszawa; 2001 [in Polish].

11. Zeidler, W. Zadowolenie z życia: Inspiracje i próby konceptualizacji [Satisfaction with Life: Inspirations and Attempts at Conceptualisation]. Prz Psychol. 2011; 54(4): 323-342 [in Polish].

12. Błachnio A, Śmiatacz K. Badania nad jakością życia polskich seniorów w czasach kryzysu [Research into the Quality of Life for Polish Seniors in Times of Crisis]. [in:] Z. Wyszkowska, M. Gotowska (ed.) Poziom i jakość życia w dobie kryzysu [The Level and Quality of Life in the Day of Crisis]. Wydawnictwo Uczelniane Uniwersytetu TechnologicznoPrzyrodniczego, Bydgoszcz; 2013: 369-383 [in Polish].

13. Fahrenberg J, Myrtek M, Brähler E, Schumacher J. Life Satisfaction Questionnaire. Primary data from the standardization sample 1994. [Translated Title] (Version 1) [Files on CD-ROM]. Trier: Center for Research Data in Psychology: Psych Data of the Leibniz Institute for
Psychology Information ZPID; 2010 https://doi.org/10.5160/psychdata. fgjn94fr12 [Pub Med].

14. Østergaard PJ, Gustafsson LN, Høyer EH, Munk-Jørgensen P. The type and prevalence of the use of analgesics among inpatients in a geriatric psychiatry department. Therap Adv Psychopharmacol. 2016; 6(1): 13-21.

15. Yagil D, Cohen M, Beer JD. Older adults' coping with the stress involved in the use of everyday technologies. J Appl Technol. 2016; 35(2): 131-149.

16. Bujnowska-Fedak M, Tomczak M. Innowacyjne aplikacje telemedyczne i usługi e-zdrowia $\mathrm{w}$ opiece nad pacjentami w starszym wieku [Innovative Applications and E-health Services for Patient Care in Old Age]. Zdr Publ Zarządz. 2013; 11(4): 302-317 [in Polish].

17. Darkins AW. Telemedicine and telehealth, Cambridge University Press, Cambridge. 2010.

18. Tanski ME, Pines JM. Alternative geriatric care and quality metrics. [in:] Kahn J H, Magauran B G Jr, Olshaker J S. (ed.) Geriatric emergency medicine: principles and practice, pp.301-312, Cambridge University Press, Cambridge. 2014.

19. Bujnowska-Fedak M, Pirogowicz I. Support for e-Health services among elderly primary care patients. Telemed J E Health. 2014; 20(8): 696-704. doi: 10.1089/tmj.2013.0318 [PubMed]

20. Kielar M. Telemedycyna w geriatrii: opieka na dziś, wyzwanie dla jutro [Telemedicine in Geriatrics: Care for Today, a Challenge for Tomorrow]. Ogólnopolski Przegl Med. 2015; 4: 14-22 [in Polish].

21. Chen K, Chan A. Use or non-use of gerontechnology - a qualitative study. Int J Environ Res Public Health. 2013; 10: 4645-4666.

22. Devis FD. Perceived Usefulness, Perceived Ease of Use, and User Acceptance of Information Technology. MIS Quarterly, 1989; 13(3): 319-340.

23. Clark PA, Capuzzi K, Harrison J. Telemedicine: Medical, legal, and ethical perspectives. Med Sci Mon. 2010; 16(12): 261-272.

24. Madden TJ, Ellen PS, Ajzen I. A Comparison of the Theory of Planned Behavior and the Theory of Reasoned Action. Pers Soc Psychol Bull. 1992; 18(1): 3-9. doi: 10.1177/0146167292181001. 